\title{
METAPHOR, HISTORY AND REALITY IN THE NEW TESTAMENT
}

D Dormeyer

University of Stellenbosch

\begin{abstract}
This article deals with the crisis of tradition. The question is whether the concept 'Gospel' plays the same role in our time as in the past, and also whether it means the same thing in Paul as in the narrative books. Mark has a paradoxical conception of 'Gospel'. Central terms and myth are also related to each other by religious metaphor. The term Christ of God is to be taken as metaphor. The Gospel of God is a weak/distant metaphor. Christians must form new metaphors in order to signify the changing of all values caused by Jesus' crucifixion and resurrection. The relation between metaphor and reality is discussed, and applied to narrative. The biographical dimension of special metaphors with proper names and of historical narratives makes it possible to bring history, historical narrative and fictional narrative into a circle, which can be traced in both directions. It is our pragmatic, rhetorical situation which determines whether the composed metaphor is to be comprehended as a distant metaphor or as a concept.
\end{abstract}

\section{Introduction}

The Traditionskrise des Glaubens, the crisis of the tradition of faith, is recognized today by all religious instances in Germany. The task of theologians is now to break the defences against Christian tradition.

But the 'crisis of tradition' is not only a problem of religion, but all sciences of human history are also touched. Therefore the science of Germanistik, of history, of philosophy seek for a common ground, to establish a wide acceptance of cultural tradition.

The German 'crisis of tradition' is certainly not the same as the cultural crisis in South Africa, but a few parallels may be outlined.

In my opinion the 'metaphor' is a central point of religious language. An excellent example is the Leit-Begriff, the central term 'gospel' (cf Dormeyer 1987). What is the syntactic, semantic and pragmatic function of such a central term? To find the answer, the metaphor is to be compared with the concept. 
If this opposition is discussed on the syntactic and semantic universal level only, it remains abstract. The pragmatic dimension needs a concrete, historical situation. Author and hearer build the framework of understanding by their competence, which they developed through their education. I agree with Combrink, that every speech is situated in a historical act of communication, and that the rhetorical situation 'has to be distinguished from the historical situation, as the rhetorical situation deals specifically with the exigence of the situation, the stasis, the basic issue of the case' (Combrink 1991:8; cf Breuer 1974, Dormeyer 1989).

The concept 'gospel' has played an important part in New Testament times and the early church of the second century (Dormeyer 1988). Does this term play the same part in our time, or has the term lost its power, and does it need another approach, an approach which this term has had in the ancient time?

This is the most basic hermeneutical question in the discussion about the central term Gospel (Frankemölle 1988). But I prefer to defer the hermeneutical actuality and to make the normal exegetical jump working on the historical books of the New Testament.

The term 'gospel' has a different use in the New Testament. Paul uses it 48 times out of the 76 times it occurs in the New Testament. In the narrations it plays no role, or just a minor role. Only in Mark the term 'gospel' has an exceptional position: it appears seven times, starting in the first verse, being the title of Mark's book 1.1.

Does 'gospel' in the letters of Paul mean the same as in the narrative books? A lifelong discussion still continues on this question. According to the Formgeschichte 'gospel' in the pre-Pauline forms denotes crucifixion and resurrection only (cf Frankemölle 1988). Paul has taken over this content.

Mark has maintained this same content. Thus there is a paradoxical conception that Mark on the one hand starts narrating with the syntagma arche euangeliou $(1,1)$, but on the other hand with the term 'gospel' merely means the last part of his narration, which is the crucifixion and resurrection of Jesus Christ, the Son of God, in chapter $14: 16,78$.

Why did the term 'gospel' become the title of all the narrative books in the second century? I will discuss the testimonies of the literal use in the second century (cf Dormeyer 1988). I think the term 'gospel' has a double meaning: kerygma (crucifixion and resurrection), and narration, in the phase of creating new forms by the Christian community. Many scholars have gone beyond the Formgeschichte, asserting this double meaning for the pre-Pauline forms, and for Paul. The textlinguistical approach to Mark will show that Mark has called the whole narrative gospel, and not only the end.

\section{The rhetorical function of central concepts and myths}

Now I will explain the main point of the rhetorical function of central terms. Why did the Christians need central terms, and why did they form new central terms? The second part of this question is widely discussed for the central term 'gospel' (cf 
Frankemölle 1988, Stuhlmacher 1968, 1983). But the first part of the question, why the Christians needed central terms, demands further explanation.

What function did a central term have in the antique rhetoric, as well as today? Rhetoric is to understand in a wide and strict sense. Barthes 1988:16f) differentiates between rhetoric as technology and rhetoric as social practice. Rhetoric as technology in the strict sense means 'all the rules and prescriptions'; rhetoric as social practice means the 'privileged technology, which allows the governing classes to remain in the possession of speech' (Barthes 1988:16f). Therefore rhetoric has not died with the destruction of the antique world; rhetoric is a permanent element of every society.

Reflection about central terms has emigrated to philosophy and other human sciences. It is well-known that the concept stands in the centre of the philosophy of Hegel, and the modern theology rotates round the construction of religious terms. Have central terms had the same importance in ancient times?

Hermann Schrödter, German philosopher of religion, draws a parallel between the terms concept and myth (1988:18):

There are interpretations of the myth, which (Hegelian spoken), ascribe it dialectic and overlapping qualities.

He quotes Levi-Strauss and others. Indeed, gospel has the function of a dialectic and overlapping quality within the Christian ancient world. In the same manner, the titles of majesty (Christ, Son of God, Son of man) have this function. Gospel has a dialectic content, because deeds by God and deeds by Jesus of Nazareth and other persons interact. Therefore gospel overlaps all areas of religious doing. Gospel has a myth-power.

Has this myth-power been lost, has this power been transformed into a philosophical term, or has it been suppressed and remained hidden? Schrödter (1988:19) enforces the classical standpoint of a German philosopher:

The differences result according to Hegel's theory, that the reign of freedom has opened itself in the 'concept' ... Consequently, a surpassing of the myth ties itself conserving its essentials, that is, the transcending of the 'concept' to the 'idea'.

Is this correct? Does the central term indeed transcend the content into the direction of idea for all people? I think this transition can't be abstracted from the pragmatic dimension, the hearer.

At this stage Lategan's question (1985:22-25) should be asked: what is the reader's response? For whom does the concept transcend to the idea, and for whom does the concept transcend to the myth?

It is a good thing that the concept opens the reign of freedom. But for whom has freedom been opened? According to Barthes only the governing classes possess freedom and can confirm their freedom with central terms. They describe their reign with central terms and determine the meaning of the central terms. But the myth 
evades determination in a multi-functional, permanent cycle of meaning. The myth works subversively.

So I see 'gospel' as a rhetorical term with the function of announcing a theological 'honour speech'. Who will understand this index? Maybe only the people with elementary education. But they will hear an announcing, which breaks their conceptmeaning.

A scholar of Greek, Günther Zuntz, has tried to identify with a highly educated antique hearer (1984:205; cf Frankemölle 1988:27f):

If this book (of Mark, author) had fallen into your hands, how would you have reacted? I fear the mere title might have scared you away: ARXH TOY EYAGGELIOU IHSOY XRISTOY: 'Incipit: The good message' ('but how about this Soloezismus here: this singular form euaggelion was never heard? Maybe, we know the plural form euaggelia. But let it be: therefore:') 'the good message of Jesus-ointment'; or maybe '... of Jesus the painted, or the made-up' (then neochriston means 'wet painted', and we know christon by medicine and sport and skin-care). That means the title was nonsense for these representative gentiles.

Will the Christians construct a new world of concept and ideas or a new world of myth? I think that the old church tried to make both: a new world of dogmatic concepts and ideas, and a new world of myths. The breaking of ancient rhetorical meaning and speech could not construct a new momentous Christian rhetoric. Augustin saw this as his task, but he was not able to change the ancient rhetoric into a Christian rhetoric. The Christian Middle Ages then dealt with this task.

Has this task been solved today? I don't think so.

\section{The religious metaphor as the main link between theological central terms and myths}

The parallelism between concept and myth is a permanent structure of religious and Christian language. The metaphor is the main link between these two fields. Of course, the representative gentiles of Zuntz have comprehended the gospel as metaphor, not as concept. So today the unphilosophical hearer will recognise gospel as metaphor, not as concept.

What does metaphor mean? How does metaphor work? I deal with a linguistic and theological definition of metaphor according to Weinrich and Weder. 'The metaphor is a contradictive predication', Weinrich (1976:308) determines in a linguistic way; while Weder (1978:62) says: 'Two principally different horizons of sense like God and world' are brought into relation to each other. The religious metaphor, however, is a matter of complex composition. God and world are to be seen as the most opposite poles that exist. So the function of metaphor is strengthened by connecting two separate parts of experience and meaning. This function is embedded in the rhetoric competence of every speaker and hearer. How did the ancient speaker and 
hearer deal with the metaphor? How do the speaker and hearer now deal with the metaphor?

Some remarks on these questions. The main Christian metaphors are composed with the name of God, the marking of a function and the proper name Jesus: Jesus the Christ of God; Jesus the Son of God; the Gospel of God ... The proper name Jesus is taken into the metaphorical event: Jesus as Christ (subject) is (copulative) God (predicate). The core of this religious metaphor is Christ of God. 'Christ' is a metonym of the ministry 'king'. Christ of God is the metaphor that signifies the divinisation of the ministry 'king' by God. The making concrete of a metaphorical relation is normal, for example in $\mathrm{x}$, the son of the devil (Jn 8:44), or the son of the desert.

But the accumulation of metaphors as used in the title Mk 1:1 is not normal. Barthes (1988:33) shows that the neo-rhetoric of the first and second century revalorizes the following embellishments: 'the archaismus, the overloaded metaphor, the antithesis, the rhythmic clausula'. All these figures are to be found in central positions in the New Testament. Kennedy (1984:89) emphasises another figure, the topic of 'the more or less', according to Aristotle. (This figure is usual in the Afrikaans ordinary language: $h y / s y / d i t$ is nie so goed nie, maar ook nie so sleg nie).

For archaisms (see the speeches in Acts), and antithesis (see the Sermon on the Mount, Mt 5:21-48; the denouncing of the Scribes and Pharisees, Mt 23, cf Lategan/Vorster 1985:22ff; the diatribes in Gl 3:13-4:13; Rm passim) the frequent use is clear, also for the overloaded metaphor. I will disregard the rhythmic clausula here. Clausula signifies apodosis and is an element of the period (Lausberg 1963:151f).

If Mark composes an overloaded metaphor in 1:1, he is in line with the neo-rhetoric of the first century. But not only Mark: all Christian speakers like the overloaded metaphors, the antitheses, the archaismus, the rhythmic clausulas, the less and more, because these figures are elements of the oral Christian tradition (Breytenbach 1986:47-58).

Where does the Christian community take this rhetoric from - from the flowery Hebraic language, or from the neo-rhetoric, or from both? I think oral tradition and written tradition on the middle level are influenced by both: by the language of the Old Testament, and the rhetoric of Greek education.

So the Christian community could form composed metaphors in order to explain and to propagate the new message of Jesus and God.

\section{Bold and distant (weak) metaphors in religious language}

A second reason for the forming of composed metaphors is the status of the religious metaphor. Usually the religious metaphor is a weak metaphor, different from the bold metaphor. When there is some tension within the metaphor between the sender and receiver of the picture, it is called a bold metaphor (Weinrich 1976:308), because the tension can easily be realized. If, on the other hand, the 
system needs further explanation to understand it, it is referred to as a distant (weak) metaphor, because the tension is likely to inhibit perception. The affinity of the far metaphor for relating philosophy and therefore relating theology, too, was already recognised by Aristotle (Rhetorik III.II.5).

According to this, 'gospel ... of God' does not belong to the bold metaphor, but to the weak metaphor. Looking for a super-ordinate term between gospel and God, one has to be content with the general situation of separation of both spheres of sense, to illustrate the tertium by the use of a further metaphor like 'Christ of God, Son of God, voice of Heaven (Mk 1:9-11), divine creation (not yet in Mark), revelation ...' The process of searching will never come to an end.

Christians must form new metaphors in order to signify the changing of all values caused by Jesus' crucifixion and resurrection. The Old Testament metaphors were too weak to signify this break. The same applies to the Greek rhetoric metaphors. But the new Christian metaphors remain weak as well. The Christian community must seek those composed metaphors which surround the most important events and show evidence of their distant/weak tension. Otherwise they freeze to concepts which are unable to signify the changing of faith.

Der neuzeitlichen Verwechselung des Mythischen mit dem Begrifflichen könnte wohl dadurch gewehrt werden, dass die Theologie einen metaphorischen Umgang mit dem Mythischen pflegt (Weder 1988:64).

\section{Metaphor, history and reality}

What relation to reality do these events and metaphors have?

On this issue, I want to make some remarks about the discussion between Lategan and Vorster in Text and Reality. Lategan quotes Umberto Eco's description of 'index'. Index means the concrete deictic sign without significat. This sign has a referent only (Lategan/Vorster 1985:90). Lategan takes king David in 2 Samuel 12 as an example. Vorster opposes the notion that in this text king David is not a historical person, but a narrative person only (Lategan/Vorster 1985:109ff). What is correct?

King David has a double function. On the one hand he is a proper name for a historical person, on the other he is a figure of narration. If one side is overlooked, the name will be a pure deictic sign without being embedded in other narratives or a pure narrative figure without relation to history. Both alternatives are wrong.

The same applies to all proper names in historical narratives of the Bible. Aristotle explains that this distinction was the basis of the differences between example and fabula in the oratio (Aristotle, Rhetorik II 20:2; Dormeyer 1987:463).

Therefore Ricoeur is right when he differentiates between narration of the first order and of the second order (Ricoeur 1987:23ff; 1986:226). But I think that he drew attention to one direction only. As in metaphor, the first order does not disappear, but has remained. So the reader can go back from the second order to the first order, comprehending the narrative within the well-known semiotic triangle 
(Eco 1977:30, quoted in Lategan 1985:83; cf also Eco 1972:69; Ricoeur, Überkreuzen der Referenz, [interchange of reference], 1987:237ff).

$\begin{array}{cc}\text { realism } & \begin{array}{c}\text { second order } \\ \text { event............................first order } \\ \text { reference }\end{array}\end{array}$

Therefore king David is a figure of realism of the second order narrative. In the first order David is a proper name of a historical king, who has done a sinful deed. This first order is a historical-critical reconstruction, not a product of fantasy.

Thus Jesus of Nazareth is the central proper name of the New Testament. In the second order Jesus is the main figure of the gospel books. In the first order Jesus is a historical person from Nazareth in Galilee, who founded a new movement, the circle of pre-Easter disciples.

At this point Lategan (1985:91) takes over the narrowing of the Formgeschichte:

Insofar as each of the gospels reveals its own narrative structure, Kermode is justified in referring to a narrative structure imposed on events (1979:117). But this process was set in motion by what the evangelist experienced as new and unique events: Jesus' life, preaching, death and resurrection.

Is it correct, that all events are new and unique in the gospels, and that the setting in motion was done by new and unique historical events only?

Therefore I agree with the continuation of the quotation, but I disagree with the following conclusion of Lategan (1985:91):

The primary impulse behind this interpretation of Jesus' message and mission and the reinterpretation of the tradition were specific occurences (cf Lategan 1973:97). This is what lies behind the christological reflection of the New Testament, the concept of a New versus an Old Testament.

The concept of a New versus an Old Testament is a fruit of the late second century. The Christian tradition and the gospel didn't want to oppose the Old Testament, but they interpreted the Old Testament as their holy book. So they put forward their interpretation of the Old Testament instead of the Jewish interpretation, but they did not want to create a new testament, a new holy book.

Jeus of Nazareth is the centre as the new interpreter. Therefore the title 'teacher' dominates the gospel narratives and also the tradition and the reconstruction of the historical Jesus according to the first order (Riesner 1980).

As Jewish teacher Jesus did many deeds which were customary according to the Jewish Culture on the narrative level as well as in history. The teacher and the other titles - prophet and miracle-healer - describe ministries which were possible and regular in the history and in the historical narrative of the first order. These titles 
convey the memory to the historical events and the elements for the construction of a historical fictional narrative.

All events implied in the ministry of the bearer of these titles were interesting for traditions and the forming of narratives.

\begin{tabular}{ll}
\multicolumn{1}{c}{ second order } & \\
event..........................first order & arrangement \\
teacher, healer $>$ reference $>$ elements & \\
& $\begin{array}{l}\text { of oral genres; } \\
\text { of written } \\
\text { hypomnemata }\end{array}$
\end{tabular}

The oral genres and written hypomnemata belong to the second order according to the narrative deep-structure. But their narrative surfaces have significant elements of the first order. The poetic transformtion of these elements to the second order construct a new narrative world, in which the titles of majesty may dominate. So I try to criticize the well-known thesis that the titles of majesty came first, followed by the historical titles of the first order (Hahn 1963). Narrative traditions of kerygmatic memory and kerygmatic traditions of faith developed in a parallel manner (Schürmann 1960; Güttgemanns 1970: Riesner 1981).

Now the historical situation 'in front of the text' is formed as a framework, Sitz im Leben, for the writing of poetic macro-genres like gospel, history and others (Lategan/Vorster 1985:86-92; 108ff). This poetic transformation is parallel to the metaphorical transformation, but not the same.

A metaphor can be without deixis. Therefore the parable is named an extended metaphor (Weinrich 1976:308; Weder 1978). But a historical narrative needs deixis. Without deixis the historical narrative becomes a parable (see Aristotle, Rhetorik II 20:2).

\begin{tabular}{ll} 
fictional: & second order \\
in front of & $\begin{array}{l}\text { fictional: } \\
\text { genres of the } \\
\text { text }\end{array}$ \\
realism & \multicolumn{1}{c}{$\begin{array}{c}\text { fabula } \\
\text { historical: }\end{array}$} \\
event.........................first order & historical: \\
$>\quad$ reference & genres of memory
\end{tabular}


The fictional arrangement dispenses with the reality of the first order, and creates a new poetic realism. The historical arrangement takes over the genres of the reality of the first order and thus exhibits deixis to the events.

Is the dispensing from the deixis the hidden ground for describing the gospels as parables today (Kelber 1983:121-131)? But what is the price of this option? Jesus becomes a fictive person of the narrative world only, an object of aesthetical enjoyment and 'thick irony' (Vorster in Lategan 1985:112). In this way religious communication is changed to aesthetical communication. But religious metaphors, narrations and forms aim at faith and religious doing. The aesthetical dimension is a second effect only (Jakobson 1972). Therefore it is necessary to revert from the second order of history narrative and religious metaphor within the religious communication to the first order, to the reconstruction of tradition.

On the other hand, the narrowing focus of the return to new and unique deeds evokes a historical Jesus, who blocks the identification, which the parable forces for religious doing and which is the spearhead of persuasive power 'in front of the text'. A Jesus who always acts anew and uniquely is a strained and unsympathetic man. Avoiding this construction of modern theology, scholars emphasize the aesthetical dimension of the Jesus-narratives.

Now the biographical dimension of special metaphors with proper names and of historical narratives enables one to point to the circularity of history, historical narrative and fictional narrative, a circle which can be followed in both directions. One may directly go from the given text to the historical reality in front of the text creating realism with myth, or one may go from the given text to historical reality reconstructing the historical narratives with proper names and other forms of deixis.

\section{biographical narrative}

mythic realism in front of the text reconstruction

event

historical narrative

proper name; genres of memory

The fictional biographical Jesus Christ, Son of God, emphasizes the identification, if the words and deeds of the human, biographical, Jesus are read. Then the mythic, divine bend of action transcends the identification conserving the human Jesus as a person of identification. On the other side the human Jesus allows the reconstruction of historical narratives and concepts disclosing the outline of the historical life of Jesus.

The transforming of historical religious experience into historical narratives and concepts, and the ongoing transforming of these narratives and concepts into poetic fictions and metaphors are essentials of Christian faith, which is also found in other religions such as the hellenistic and Latin divinisation of heroes and other grand men of history (see Plutarch, Bioi; Aune 1987; Dormeyer 1988). 


\section{biography}

kerygmatic realism kerygmatic arrangement

event historical narratives, concepts

This process is still continuing today, but the canon has set a preliminary end by the conclusion of the New Testament.

\section{End}

It is our pragmatic, rhetorical situation which determines whether the composed metaphor is to be comprehended as a distant metaphor or as a concept. The distant metaphor has to be filled with our own experience, the concept has to be decoded by its given content.

The interpreting of religious terms as concepts establishes the possession of speech and interpreting them as metaphors opens the religious language for the competence of all native speakers. The gospels have both, metaphors and concepts. All concepts must not be comprehended as metaphors (cf law), but all metaphors must not be restricted to concepts. Here is a wide field determining the biblical head-terms as concepts or as metaphors with all its syntactic, semantic and pragmatic implications.

So the gospels are anonymous works. All Christian communities have recognized their intentions in the gospels. The explanation that they are biographies of anonymous authors and the thoroughgoing use of metaphors and concepts within the gospels have made the gospels the most important books for Christian readers' response.

Divine inspiration is not an instrument for the forcing of obedience, but the result of the common consensus of reading in the second century, of reading as taking place within a framework of biography, metaphors and central concepts.

Would this common tradition have grown, if the Jesus-books had only consisted of concepts and divine facts without human biography and metaphors? Did these books remain on the first order of concepts and historical theological narratives - that is crucifixion and resurrection as kerygma only, according to Bultmann - while the second fictional order has to do with the depicting, the picturing of the kerygma only? Would this common tradition have grown, if the Jesus-books had only consisted of poetic fictional narratives and poetic metaphors, and would they have been read with uninterested pleasure without asking back to the historical reality?

There are many hints in the discussions of the first and second centuries that the relationship with Jesus Christ always had biographic and metaphorical dimensions with reference to his past history.

Is the Christian tradition broken because the present, historical-critical approach has lost its biographical and metaphorical dimensions and has refused to transcend to 
the order of poetry, fiction and metaphor? And is the emphasis of the poetic function the best way of healing this break of tradition?

These questions indicate in which direction the interpretation of biblical metaphors has to go.

\section{BIBLIOGRAPHY}

Aune, D E 1987. The New Testament in its literary environment. Philadelphia.

Barthes, R 1988. Die alte Rhetorik, in Das semiologische Abenteur (es 1441), 15-102. Frankfurt. (fr. 1985).

Breuer, D 1974. Einführung in die pragmatische Texttheorie. München.

Breytenbach, C 1986. Das Problem des Übergangs von mündlicher zu schriftlicher Tradition. Neotestamentica 20.

Combrink, H J B. Reference and rhetoric in the gospel of Matthew.

Dormeyer, D 1987. Die Kompositionsmetapher 'Evangelium Jesu Christi, des Sohnes Gottes' Mk 1,1. Ihre theologische und literarische Aufgabe in der JesusBiographie des Markus. NTS 33, 452-468.

Dormeyer, D 1988. Evangelium als literarische und theologische Gattung. Erträge der Forschung 263. Darmstadt.

Dormeyer, D 1989. The implicit and explicit reader and the genre of Philippians 3:24; 8-9. Semeia.

Eco, U 1972. Einführung in die Semiotik. München. (Ital. 1968).

Eco, U 1977. Zeichen. Frankfurt.

Frankemölle, H 1988. Evangelium. Begriff und Gattung. Stuttgart.

Güttgemanns, E 1970. Offene Fragen zur Formgeschichte des Evangeliums. (BEvTh 54.) München.

Hahn, F 1963. Christologische Hoheitstitel. Ihre Geschichte im frühen Christentum. (FRLANT 83.) Göttingen.

Jakobson, R 1972. Linguistik und Poetik, in Ihwe, J (Hrsg), Literaturwissenschaft und Linguistik 1 (FAT 2015), 99-136. Frankfurt.

Kelber, W H 1983. The oral and written gospel. Philadelphia.

Kennedy, G A 1984. New Testament interpretation through rhetorical criticism. The University of North Carolina Press.

Kermode, F 1979. The Genesis of secrecy. Cambridge, MA: Harvard University Press.

Lategan, B C \& Vorster, W 1985. Text and reality. Philadelphia: Atalanta. 
Lausberg, H 1963. Elemente der literarische Rhetorik. München.

Louw, J P 1982. Semantics of New Testament Greek. Philadelphia: Chico.

Ricoeur, P 1987. Erzählung, Matapher und Interpretationstheorie. ZThK 84. 232254.

Ricoeur, P 1986. Die lebendige Metapher (fr. 1975), München.

Riesner, R 1981. Jesus als Lehrer. Eine Untersuchung zum Ursprung der EvangelienÜberlieferung (WUNT 2,7), Tübingen.

Schrödter, H. 'Neo-Mythen'. Überlegungen zu Begriff und Problem einer 'mythischen Kehre'. MS.

Schürmann, H 1968. Die vorösterlichen Anfänge der Logientradition. Versuch eines formgeschichtlichen Zugangs zum Leben Jesu (1960), in Schürmann, H. Traditionsgeschichtliche Untersuchungen zu den synoptischen Evangelien, 39-65. Düsseldorf.

Stuhlmacher, P 1968. Das paulische Evangelium. 1 Vorgeschichte (FRLANT 95.) Göttingen.

Stuhlmacher, P (Hrsg) 1983. Das Evangelium und die Evangelien (WUNT 1,28). Tübingen.

Weder, H 1978. Die Gleichnisse Jesu als Metaphern. Traditions- und redaktionsgeschichtliche Analysen und Interpretationen. (FRLANT 120). Göttingen.

Weder, H 1988. Der Mythos vom Logos (Johannes 1). Überlegungen zur Sachproblematik der Entmythologisierung, in Schmid, H H (Hrsg), Mythos und Rationalität, 44-75. Gütersloh.

Weinrich, H 1976. Sprache in Texten. Stuttgart.

Zuntz, G 1984. Ein Heide las das Markusevangelium, in Cancik, H (Hrsg), Markus- Philologie (WUNT 33), 205-222. Tübingen. 